\title{
A Simple and Efficient Two-Dimensional High-Speed Counter-Current Chromatography Linear Gradient and Isocratic Elution Modes for the Preparative Separation of Coumarins from Roots of Toddalia asiatica (Linn.) Lam.
}

\author{
Wenya Ma ${ }^{1,2}$, Iftikhar Ali ${ }^{2,3}{ }^{(D)}$, Yali Li ${ }^{4}$, Hidayat Hussain ${ }^{5}$ (D) Huanzhu Zhao ${ }^{2}$, Xuan Sun ${ }^{2}$, Lei Xie ${ }^{2}$, Li Cui ${ }^{2, *}$ \\ and Daijie Wang $1,2, *$
}

check for updates

Citation: Ma, W.; Ali, I.; Li, Y.; Hussain, H.; Zhao, H.; Sun, X.; Xie, L.; Cui, L.; Wang, D. A Simple and Efficient Two-Dimensional High-Speed Counter-Current Chromatography Linear Gradient and Isocratic Elution Modes for the Preparative Separation of Coumarins from Roots of Toddalia asiatica (Linn.) Lam. Molecules 2021, 26, 5986. https://doi.org/10.3390/ molecules26195986

Academic Editor: Patrick Chaimbault

Received: 30 August 2021

Accepted: 28 September 2021

Published: 2 October 2021

Publisher's Note: MDPI stays neutral with regard to jurisdictional claims in published maps and institutional affiliations.

Copyright: (c) 2021 by the authors. Licensee MDPI, Basel, Switzerland. This article is an open access article distributed under the terms and conditions of the Creative Commons Attribution (CC BY) license (https:/ / creativecommons.org/licenses/by/ $4.0 /)$.
1 College of Life Science, Shandong Normal University, Jinan 250014, China; wenyama97@126.com

2 School of Pharmaceutical Sciences and Key Laboratory for Applied Technology of Sophisticated Analytical Instruments of Shandong Province, Shandong Analysis and Test Center, Qilu University of Technology (Shandong Academy of Sciences), Jinan 250014, China; iftikhar.ali@kiu.edu.pk (I.A.); 17864170352@163.com (H.Z.); sx951009@163.com (X.S.); xieleito@gmail.com (L.X.)

3 Department of Chemistry, Karakoram International University, Gilgit 15100, Pakistan

4 Key Laboratory of the Innovative, Development of Functional Staple and the Nutritional, Intervention for Chronic Disease, China National Research Institute of Food \& Fermentation Industries Co., Ltd., Beijing 100015, China; cnliyali@163.com

5 Department of Bioorganic Chemistry, Leibniz Institute of Plant Biochemistry, Weinberg 3, D-06120 Halle (Saale), Germany; hussainchem3@gmail.com

* Correspondence: cuili@qlu.edu.cn (L.C.); wangdaijie@qlu.edu.cn or wangdaijie@126.com (D.W.); Tel.: +86-0531-8260-5319 (L.C.); Fax: +86-0531-8296-4889 (L.C.)

Abstract: Toddalia asiatica (L.) Lam. (Rutaceae) has shown a broad spectrum of biological properties, such as anti-inflammatory, antioxidant, antimicrobial, anti-HIV, and anticancer properties. The present study is concerned with the separation of the main components with broad partition coefficients ( $K_{\mathrm{D}}$ values) from $T$. asiatica, using linear gradient high-speed counter-current chromatography (LGCCC) combined with an off-line two-dimensional (2D) mode. Similar to the binary gradient HPLC, the LGCCC mode is operated by the adjustment of the proportion between the mobile phase of 5:5:1:9 $(v / v)$ (pump A) and 5:5:4.5:5.5 $(v / v)$ (pump B) in an $n$-hexane/ethyl acetate/methanol/water solvent system. The off-line 2D-CCC mode was used in this study for the secondary separation of two similar $K_{\mathrm{D}}$ value compounds with $n$-hexane/ethyl acetate/methanol/water (5:5:4:6, $\left.v / v\right)$. Notably, six coumarins, namely, tomentin (1), toddalolactone (2), 5,7,8-trimethoxycoumarin (3), mexoticin (4), isopimpinellin (5), and toddanone (6), were efficiently separated. The structures of the pure compounds were elucidated by spectral techniques and compared with the literature.

Keywords: Toddalia asiatica (L.) Lam.; high-speed counter-current chromatography; coumarins; linear gradient

\section{Introduction}

Toddalia asiatica (L.) Lam. (Rutaceae) is used in traditional medicine and is reported to treat wounds, pain, swelling, fever, malaria, diarrhea, cancer, coughs, and stomach infections. In addition, this plant exhibits anti-inflammatory, antioxidant, antibacterial, and antifungal properties [1-4]. Furthermore, T. asiatica is reported to treat epilepsy [5]. The literature reveals that various natural products, including alkaloids, quinolone derivatives, coumarins, and essential oils, are derived from T. asiatica, which has shown antidiabetic [6], anti-HIV [7], anticancer [8], antibacterial [9], antiplasmodial [10], antifungal, antibacterial [4], anti-inflammatory [11], and antiviral [12] properties.

Previous studies show that different methods, such as GC/MS [3,13-15], HPLC [16-18], UPLC-MS/MS [19] UPLC-QTOF-MS/MS [17], and HPTLC [20], can be used for the purification of the chemical constitutes in T. asiatica. High-speed counter-current chromatography 
(HSCCC) using the $n$-hexane/ethyl acetate/methanol/water (10:10:11:9, $v / v)$ solvent system is reported for the separation of isopimpinellin, pimpinellin, and phellopterin from T. asiatica [21]. Recently, in a previous study conducted by our group, the $n$-hexane/ethyl acetate/methanol/water (5:5:3:7, $v / v)$ biphasic solvent system was successfully used to separate toddalolactone, leptodactylone, haplopine, skimmianine, and 5-methoxydictamnine from T. asiatica [22].

In this study, a more efficient separation of components from T. asiatica is established using a two-dimensional high-speed counter-current chromatography (HSCCC) linear gradient and isocratic elution modes. Similar to the binary gradient HPLC, the LGCCC mode is operated by an adjustment of the proportion between the mobile phase of 5:5:1:9 $(v / v)$ (pump A) and 5:5:4.5:5.5 (v/v) (pump B) in an n-hexane/ethyl acetate/methanol/water solvent system. The off-line 2D-CCC mode was used for the secondary separation of two similar $K_{\mathrm{D}}$ value compounds with $n$-hexane/ethyl acetate/methanol/water (5:5:4:6, v/v). Notably, six coumarins, namely, tomentin (1), toddalolactone (2), 5,7,8-trimethoxycoumarin (3), mexoticin (4), isopimpinellin (5), and toddanone (6), were efficiently separated (Figure 1). Recently, HSCCC has been used to effectively separate a variety of components from plant species [23-25].<smiles>[R][Y](=O)C[C@H](O)C(C)(C)O</smiles>

1: $\mathrm{R}_{1}=\mathrm{OH}, \mathrm{R}_{2}=\mathrm{R}_{3}=\mathrm{OCH}_{3}, \mathrm{R}_{4}=\mathrm{H}$

2: $\mathrm{R}_{1}=\mathrm{OCH}_{3}, \mathrm{R}_{2}=\mathrm{R}, \mathrm{R}_{3}=\mathrm{OCH}_{3}, \mathrm{R}_{4}=\mathrm{H}$

3: $\mathrm{R}_{1}=\mathrm{OCH}_{3}, \mathrm{R}_{2}=\mathrm{H}, \mathrm{R}_{3}=\mathrm{R}_{4}=\mathrm{OCH}_{3}$

4: $\mathrm{R}_{1}=\mathrm{OCH}_{3}, \mathrm{R}_{2}=\mathrm{H}, \mathrm{R}_{3}=\mathrm{OCH}_{3}, \mathrm{R}_{4}=\mathrm{R}$

5: $\mathrm{R}_{1}=\mathrm{OCH}_{3}, \mathrm{R}_{2} \mathrm{R}_{3}=-(\mathrm{CH})_{2} \mathrm{O}-, \mathrm{R}_{4}=\mathrm{OCH}_{3}$

6: $\mathrm{R}_{1}=\mathrm{OCH}_{3}, \mathrm{R}_{2}=-\mathrm{CH}_{2} \mathrm{COCHMe}_{2}, \mathrm{R}_{3}=\mathrm{OCH}_{3}$, $\mathrm{R}_{4}=\mathrm{H}$

Figure 1. Chemical structures of compounds 1-6 separated from T. asiatica.

The structures of the pure compounds were elucidated by ${ }^{1} \mathrm{H}$ - and ${ }^{13} \mathrm{C}-\mathrm{NMR}$, and ESIMS (positive/negative ion mode). Furthermore, the spectral information was compared with that of previous studies.

\section{Results}

\subsection{Selection of the HSCCC Solvent System}

A successful separation of the target compounds using HSCCC requires a careful search for a suitable two-phase solvent system to provide an ideal range of $K_{\mathrm{D}}$ values from 0.5 to 2 . Higher $K_{\mathrm{D}}$ values may lead to extended elution times and excessively broad peaks, whereas lower $K_{\mathrm{D}}$ values might lead to poor peak resolution [26]. In the present experiment, a series of solvent systems were tested with $n$-hexane/ethyl acetate/methanol/water (5:5:X:10-X, $v / v)$. As shown in Table 1 , the $K_{\mathrm{D}}$ values of the six target compounds were successfully spread. 
Table 1. The $K_{\mathrm{D}}$ values of target compounds in HSCCC with different solvent systems.

\begin{tabular}{cccccccc}
\hline \multirow{2}{*}{$\begin{array}{c}\text { Compound } \\
\text { No. }\end{array}$} & $\mathbf{5} K_{\mathrm{D}}$ Values $(\boldsymbol{n}$-Hex/EtOAc/MeOH/H $\mathbf{2} \mathbf{O}, \boldsymbol{v} / \boldsymbol{v})$ \\
\cline { 2 - 8 } & $\mathbf{5 : 5 : 9}$ & $\mathbf{5 : 5 : 2 : 8}$ & $\mathbf{5 : 5 : 3 : 7}$ & $\mathbf{5 : 5 : 4 : 6}$ & $\mathbf{5 : 5 : 4 . 5 : 5 . 5}$ & $\mathbf{5 : 5 : 5 : 5}$ & $\mathbf{5 : 5 : 6 : 4}$ \\
\hline $\mathbf{1}$ & 1.74 & 0.90 & 0.66 & 0.33 & 0.24 & $<0.20$ & $<0.20$ \\
$\mathbf{2}$ & 0.94 & 0.53 & 0.40 & 0.21 & $<0.20$ & $<0.20$ & $<0.20$ \\
$\mathbf{3}$ & $>5.00$ & 4.27 & 2.94 & 1.17 & 0.94 & 0.54 & 0.25 \\
$\mathbf{4}$ & $>5.00$ & $>5.00$ & 3.23 & 1.28 & 1.05 & 0.62 & 0.30 \\
$\mathbf{5}$ & $>5.00$ & $>5.00$ & $>5.00$ & 2.89 & 2.35 & 1.25 & 0.52 \\
$\mathbf{6}$ & $>5.00$ & $>5.00$ & $>5.00$ & 3.20 & 2.68 & 1.49 & 0.68 \\
\hline
\end{tabular}

When the solvent system $n$-hexane/ethyl acetate/methanol/water (5:5:1:9, v/v) was used, the $K_{\mathrm{D}}$ values of compounds 1 and 2 were suitable, whereas compounds 3-6 were larger than 5 and needed a long elution time. On the other hand, when the ratio of methanol was increased, the $K_{\mathrm{D}}$ values decreased gradually. When the solvent system $n$-hexane/ethyl acetate/methanol/water $(5: 5: 4: 6, v / v)$ was used, the $K_{\mathrm{D}}$ values of compounds 3 and 4 were suitable, whereas compounds 1 and 2 were smaller than 0.5 and had a poor resolution. Furthermore, compounds 5 and $\mathbf{6}$ were slightly larger with a long elution time. When the solvent system $n$-hexane/ethyl acetate/methanol/water (5:5:5:5, v/v) was used, the $K_{\mathrm{D}}$ values of compounds 5 and $\mathbf{6}$ were suitable, whereas compounds $\mathbf{1 - 4}$ were smaller. The above results indicated that the $K_{\mathrm{D}}$ values spanned a wide range, and so it was difficult to separate them with a single solvent system. LGCCC separation was chosen to separate coumarins from the roots of T. asiatica. According to the results of the tested $K_{\mathrm{D}}$ values, the lower phase of $n$-hexane/ethyl acetate/methanol/water (5:5:1:9, $v / v)$ was used as mobile phase A, while $n$-hexane/ethyl acetate/methanol/water (5:5:5:5, 5:5:6:4, $v / v)$ was selected as mobile phase B to build the 5:5:X:10-X $(v / v)$ solvent system for LGCCC elution.

\subsection{Optimization of HSCCC Conditions}

Figure 2 shows the retention of stationary phase $\left(R_{\mathrm{S}}\right)$ testing of the LGCCC mode. The stationary phase was used as the upper phase of $n$-hexane/ethyl acetate/methanol/water $(5: 5: 1: 9, v / v)$, while the mobile phase was set as the mobile phase of $n$-hexane/ethyl acetate/methanol/water (5:5:1:9, v/v) (mobile phase A). Another LGCCC mobile phase (mobile phase B) was tested with different $n$-hexane/ethyl acetate/methanol/water solvent systems that had a linear elution condition of $0-157.5 \mathrm{~min}, 0-100 \% \mathrm{~B}$, and $157.5-300 \mathrm{~min}$, $100 \% \mathrm{~B}$. The CCC flow direction was in head-to-tail mode with a flowrate of $5.0 \mathrm{~mL} / \mathrm{min}$. When mobile phase B was used as $n$-hexane/ethyl acetate/methanol/water (5:5:6:4,v/v), the loss of $R_{\mathrm{S}}$ was obvious with only $7.14 \%$ at $300 \mathrm{~min}$. This indicated that it would affect the separation effect with the loss of the stationary phase. When the $n$-hexane/ethyl acetate/methanol/water (5:5:5:5, $v / v$ ) solvent system was used, the loss of $R_{\mathrm{S}}$ was improved; however, the $R_{\mathrm{S}}$ was only $11.43 \%$. Although the $n$-hexane/ethyl acetate/methanol/water $(5: 5: 5: 5, v / v)$ solvent system was suitable for separation compounds 5 and $\mathbf{6}$, the loss of $R_{S}$ indicated that it was not suitable to build an LGCCC solvent system. In this case, mobile phase B was tested as $n$-hexane/ethyl acetate/methanol/water (5:5:4.5:5.5, v/v) and a good $R_{\mathrm{S}}$ result of over $40 \%$ was obtained at $300 \mathrm{~min}$. When $n$-hexane/ethyl acetate/methanol/water (5:5:4:6, $v / v)$ and other hydrophilic mobile phases were used, the elution time was longer with an increased amount of solvent consumption. The above results indicate that a careful evaluation of the $R_{\mathrm{S}}$ value of the two mobile phases for a suitable LGCCC separation is necessary.

Figure 3 shows the HSCCC of the crude extract of coumarins from the roots of T. asiatica. The LGCCC mobile phase comprised of mobile phase A and B with a linear gradient elution of $0-157.5 \mathrm{~min}, 0-100 \% \mathrm{~B}$, and $157.5-360 \mathrm{~min}, 100 \% \mathrm{~B}$. The upper phase of $n$-hexane/ethyl acetate/methanol/water $(5: 5: 1: 9, v / v)$ was used as the stationary phase in head-to-tail elution mode with a flowrate $5.0 \mathrm{~mL} / \mathrm{min}$. The retention of the stationary phase was $40.3 \%$ with a total separation time of $360 \mathrm{~min}$. As shown in Figure 3, after one-step separation, five main peaks were obtained: peak I (19.3 mg), peak II (31.4 mg), peak III (29.9 mg), peak 
IV (36.3 mg), and peak V (8.7 mg). Peak I, peak II, peak IV, and peak V correspond to compounds 2, 1, 5, and 6, respectively, each with the purities over $98 \%$, as determined by HPLC. Peak III was a mixture of compounds 3 and 4.

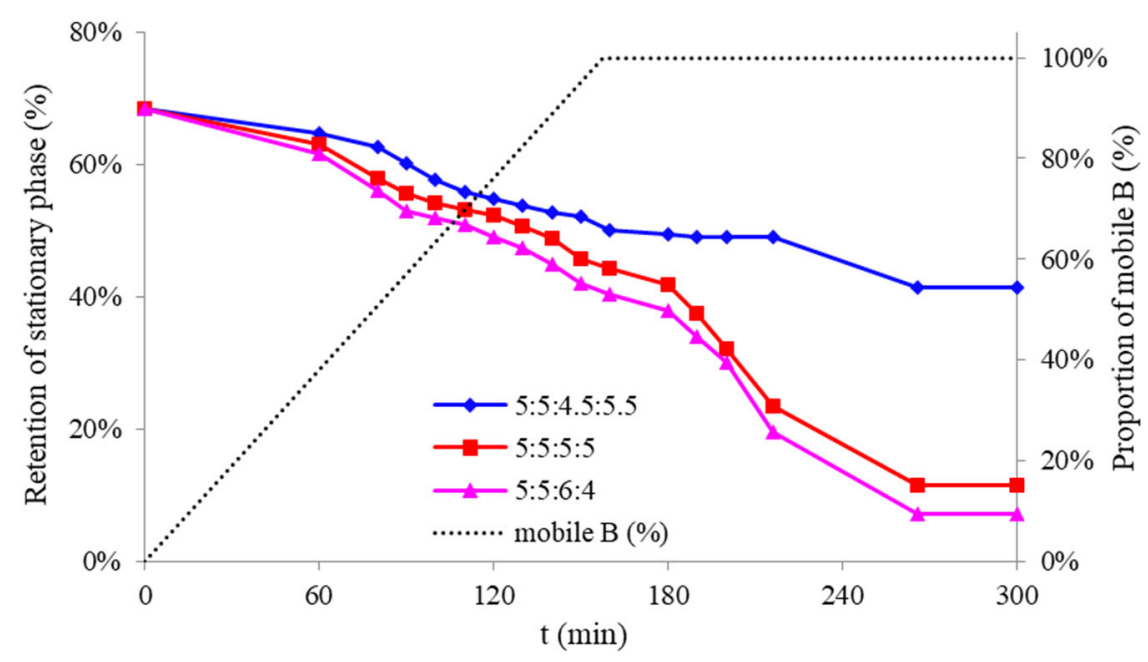

Figure 2. The linear gradient CCC procedure tested with different solvent systems. Stationary phase: upper phase of $n$-hexane/ethyl acetate/methanol/water (5:5:1:9, $v / v)$; mobile phase: lower phase of $n$-hexane/ethyl acetate/methanol/water $(5: 5: 1: 9, v / v)$ as mobile A and lower phase of n-hexane/ethyl acetate/methanol/water (5:5:4.5:5.5, 5:5:5:5, 5:5:6:4, $v / v$ ) as mobile B; linear elution condition: 0-157.5 min, 0-100\% B, and 157.5-300 $\mathrm{min}, 100 \% \mathrm{~B}$; and flowrate: $5.0 \mathrm{~mL} / \mathrm{min}$.

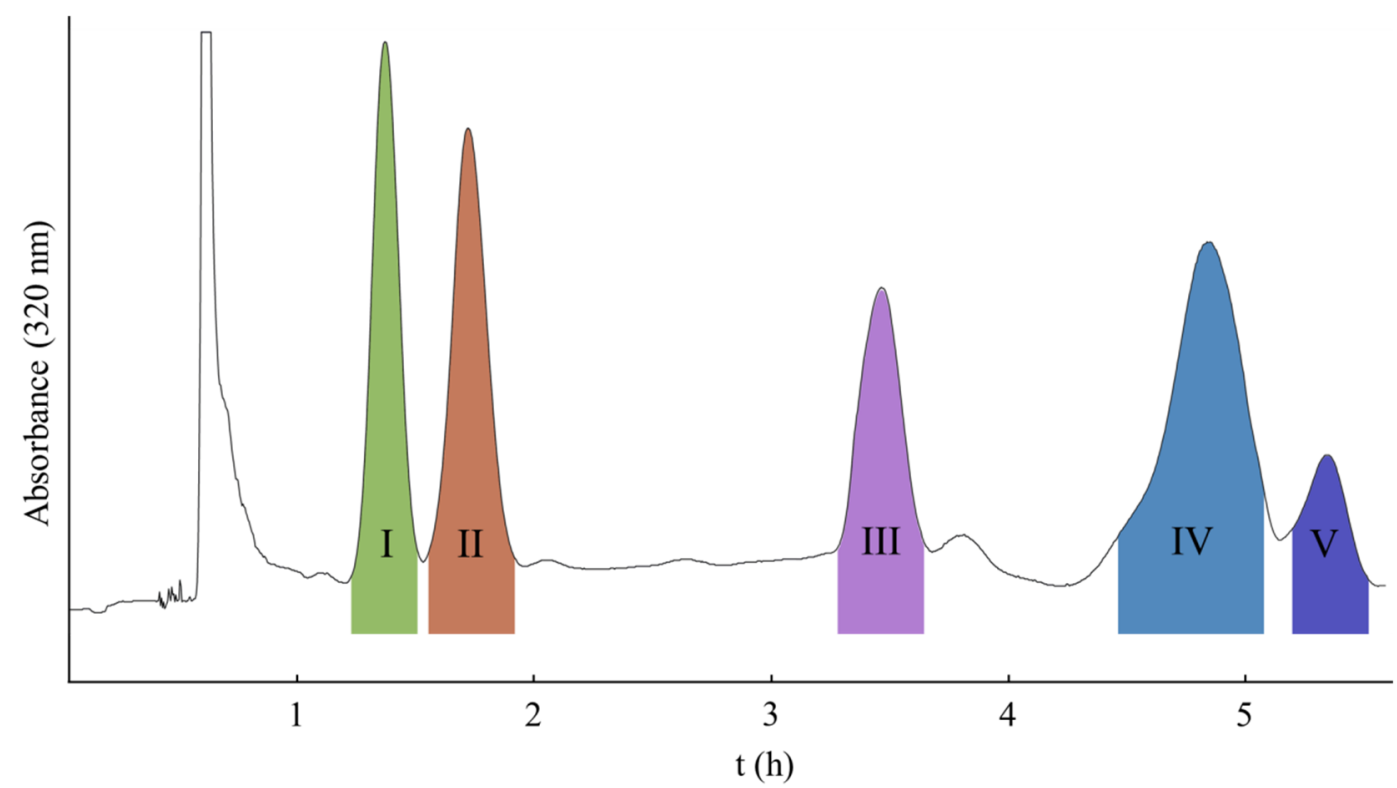

Figure 3. The linear gradient CCC procedure on the separation of coumarins from the roots of T. asiatica. Stationary phase: upper phase of $n$-hexane/ethyl acetate/methanol/water (5:5:1:9, v/v); mobile phase: lower phase of $n$-hexane/ethyl acetate/methanol/water (5:5:1:9, $v / v)$ as mobile A and lower phase of $n$-hexane/ethyl acetate/methanol/water (5:5:4.5:5.5, $v / v$ ) as mobile B; linear elution condition: 0-157.5 min, 0-100\% B, and 157.5-360 $\mathrm{min}, 100 \% \mathrm{~B}$; flowrate: $5.0 \mathrm{~mL} / \mathrm{min}$; and detection wavelength: $320 \mathrm{~nm}$.

Figure 4 shows the off-line dimensional separation of peak III in Figure 3, in which a traditional HSCCC mode with a solvent system of $n$-hexane/ethyl acetate/methanol/water $(5: 5: 4: 6, v / v)$ was used in head-to-tail elution mode with a flowrate of $2.0 \mathrm{~mL} / \mathrm{min}$. The upper phase was used as the stationary phase. The retention of the stationary phase was 
$61.3 \%$ with a total separation time of $300 \mathrm{~min}$. As shown in Figure 4, two peaks were obtained with I $(7.9 \mathrm{mg})$ and II $(16.7 \mathrm{mg})$ and corresponded to compounds 3 and 4 . The purities were over $98 \%$, as determined by HPLC (Figure 5).

\subsection{Structure Identification}

Tomentin 1 [26], (peak 1 in Figure 5), $\mathrm{C}_{11} \mathrm{H}_{10} \mathrm{O}_{5}$, ESI-MS (positive ion mode) $\mathrm{m} / \mathrm{z}$ $223.0657[\mathrm{M}+\mathrm{H}]^{+}$. ${ }^{1} \mathrm{H}-\mathrm{NMR}\left(\mathrm{DMSO}-d_{6}, 400 \mathrm{MHz}\right) \delta_{\mathrm{H}}: 8.83(1 \mathrm{H}$, br s, OH-5), $8.00(1 \mathrm{H}, \mathrm{d}$, $J=9.7 \mathrm{~Hz}, \mathrm{H}-4), 6.67(1 \mathrm{H}, \mathrm{s}, \mathrm{H}-8), 6.15(1 \mathrm{H}, \mathrm{d}, J=9.7, \mathrm{H}-3), 3.92\left(3 \mathrm{H}, \mathrm{s},-\mathrm{OCH}_{3}\right), 3.89(3 \mathrm{H}, \mathrm{s}$, - $\left.\mathrm{OCH}_{3}\right) .{ }^{13} \mathrm{C}-\mathrm{NMR}\left(\mathrm{DMSO}-d_{6}, 100 \mathrm{MHz}\right) \delta_{\mathrm{C}}: 160.6(\mathrm{C}-2), 152.3(\mathrm{C}-7), 149.2(\mathrm{C}-9), 143.9(\mathrm{C}-5)$, 139.5 (C-4), 127.6 (C-6), 110.9 (C-3), 103.4 (C-10), $93.2(\mathrm{C}-8), 56.9\left(-\mathrm{OCH}_{3}\right), 56.8\left(-\mathrm{OCH}_{3}\right)$.

Toddalolactone $2[27,28]$, (peak 2 in Figure 5), $\mathrm{C}_{16} \mathrm{H}_{20} \mathrm{O}_{6}$, ESI-MS (positive ion mode) $m / z 309.1328[\mathrm{M}+\mathrm{H}]^{+} .{ }^{1} \mathrm{H}-\mathrm{NMR}\left(\mathrm{DMSO}-d_{6}, 400 \mathrm{MHz}\right) \delta_{\mathrm{H}}: 8.01(1 \mathrm{H}, \mathrm{d}, J=9.6 \mathrm{~Hz}, \mathrm{H}-4)$, $6.85(1 \mathrm{H}, \mathrm{s}, \mathrm{H}-8), 6.28(1 \mathrm{H}, \mathrm{d}, J=9.6 \mathrm{~Hz}, \mathrm{H}-3), 3.87$ (3H, s, -OMe), 3.85 (3H, s, -OMe), 3.55 $\left(1 \mathrm{H}\right.$, merged with solvent peak, $\left.\mathrm{H}-2^{\prime}\right), 3.17\left(1 \mathrm{H}, \mathrm{H}-1^{\prime} \mathrm{a}\right), 2.66\left(1 \mathrm{H}, \mathrm{m}, \mathrm{H}-1^{\prime} \mathrm{b}\right), 2.52(1 \mathrm{H}, \mathrm{br} \mathrm{s}$, -OH), $1.81(1 \mathrm{H}$, br s, $-\mathrm{OH}), 1.13\left(6 \mathrm{H}\right.$, merged s, $\left.-\mathrm{CH}_{3}\right) .{ }^{13} \mathrm{C}-\mathrm{NMR}$ (DMSO- $\left.d_{6}, 100 \mathrm{MHz}\right) \delta_{\mathrm{C}}$ : 162.0 (C-2), 160.4 (C-7), 156.0 (C-5), 154.3 (C-9), 139.8 (C-4), 119.2 (C-6), 111.8 (C-3), 106.8 (C-10), 95.4 (C-8), $75.8\left(\mathrm{C}-2^{\prime}\right), 72.1\left(\mathrm{C}-3^{\prime}\right), 63.1$ (7-OMe), 56.4 (5-OMe), $25.9\left(\mathrm{C}-5^{\prime}\right), 25.6\left(\mathrm{C}-4^{\prime}\right)$, $25.4\left(\mathrm{C}-1^{\prime}\right)$.

5,7,8-Trimethoxycoumarin 3 [29], (peak 3 in Figure 5), $\mathrm{C}_{12} \mathrm{H}_{12} \mathrm{O}_{5}$, ESI-MS (positive ion mode) $m / z 237.0727[\mathrm{M}+\mathrm{H}]^{+} .{ }^{1} \mathrm{H}-\mathrm{NMR}\left(\mathrm{DMSO}-d_{6}, 400 \mathrm{MHz}\right) \delta_{\mathrm{H}}: 8.02(1 \mathrm{H}, \mathrm{d}, J=9.7 \mathrm{~Hz}$, $\mathrm{H}-4), 6.69(1 \mathrm{H}, \mathrm{s}, \mathrm{H}-6), 6.19(1 \mathrm{H}, \mathrm{d}, J=9.7 \mathrm{~Hz}, \mathrm{H}-3), 3.95\left(3 \mathrm{H}, \mathrm{s},-\mathrm{OCH}_{3}, \mathrm{H}-8\right), 3.93(3 \mathrm{H}, \mathrm{s}$, $\left.-\mathrm{OCH}_{3}, \mathrm{H}-5\right), 3.74\left(3 \mathrm{H}, \mathrm{s},-\mathrm{OCH}_{3}, \mathrm{H}-7\right) .{ }^{13} \mathrm{C}-\mathrm{NMR}$ (DMSO- $\left.d_{6}, 100 \mathrm{MHz}\right) \delta_{\mathrm{C}}: 160.9$ (C-2), 156.6 (C-5), 152.6 (C-7), 148.3 (C-4), 139.5 (C-8b), 129.7 (C-8), 111.2 (C-3), 103.4 (C-8a), 93.2 (C-6), $61.2\left(-\mathrm{OCH}_{3}\right), 57.0\left(-\mathrm{OCH}_{3}\right), 56.9\left(-\mathrm{OCH}_{3}\right)$.

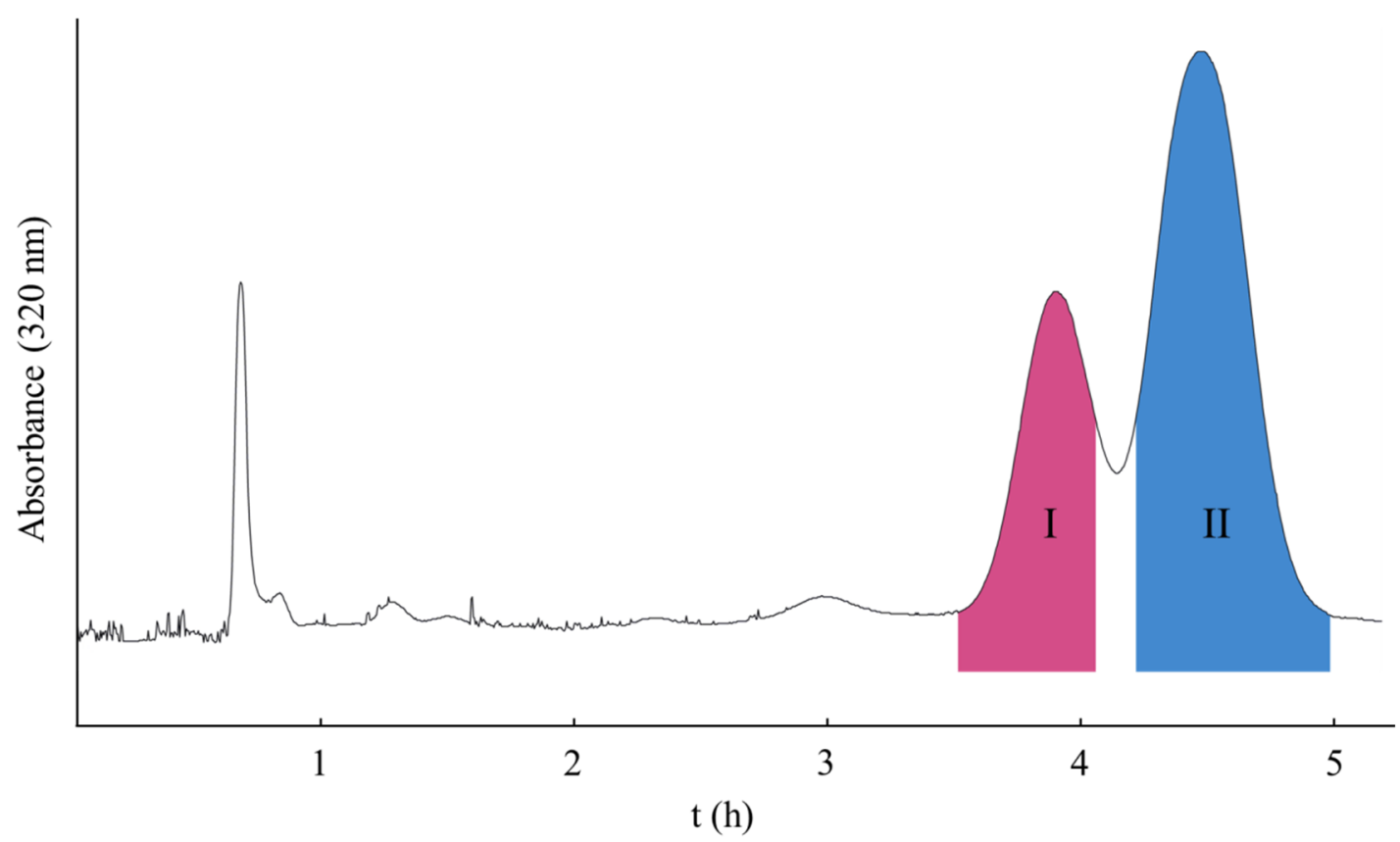

Figure 4. The off-line dimensional CCC procedure on the separation of peak III in Figure 2; solvent system: $n$-hexane/ethyl acetate/methanol/water (5:5:4:6, v/v); flowrate: $2.0 \mathrm{~mL} / \mathrm{min}$; and detection wavelength: $320 \mathrm{~nm}$. 


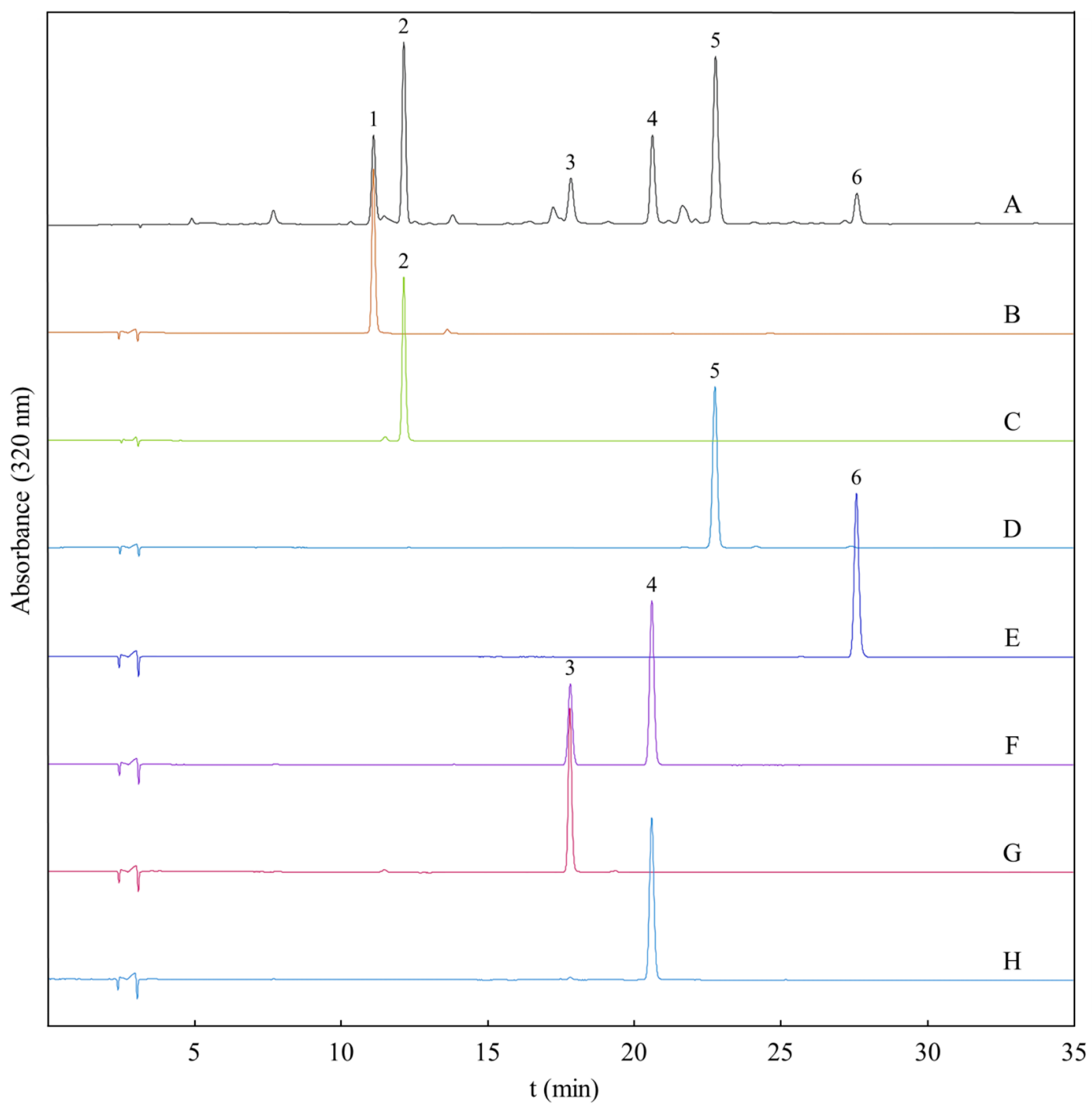

Figure 5. HPLC chromatograms of the crude extract and the isolated coumarins. Experimental conditions: Zobax SB $\mathrm{C}_{18}$ column (5 $\mu \mathrm{m}, 4.6 \mathrm{~mm} \times 250 \mathrm{~mm}$, i.d.); mobile phase: water (A) and acetonitrile (B) in a linear elution mode of 0-30 min, 22-55\% B; 30-31 min, 55-95\% B; and 34-35 min, 95-22\% B. Flowrate: $1.0 \mathrm{~mL} / \mathrm{min}$; and detection: $320 \mathrm{~nm}$. (A): crude extract; (B): peak II in Figure 3; (C): peak I in Figure 3; (D): peak IV in Figure 3; (E): peak V in Figure 3; (F): peak III in Figure 3; (G): peak I in Figure 4; and (H): peak II in Figure 4.

Mexoticin 4 [30], (peak 4 in Figure 5), $\mathrm{C}_{16} \mathrm{H}_{20} \mathrm{O}_{6}$, ESI-MS (positive ion mode) $\mathrm{m} / \mathrm{z}$ $309.1285[\mathrm{M}+\mathrm{H}]^{+} .{ }^{1} \mathrm{H}-\mathrm{NMR}\left(\mathrm{DMSO}-d_{6}, 400 \mathrm{MHz}\right) \delta_{\mathrm{H}}: 8.00(1 \mathrm{H}, \mathrm{d}, J=9.6 \mathrm{~Hz}, \mathrm{H}-4), 6.87$ $(1 \mathrm{H}, \mathrm{s}, \mathrm{H}-6), 6.27(1 \mathrm{H}, \mathrm{d}, J=9.6 \mathrm{~Hz}, \mathrm{H}-3), 3.87\left(3 \mathrm{H}, \mathrm{s}, \mathrm{OCH}_{3}\right), 3.85\left(3 \mathrm{H}, \mathrm{s}, \mathrm{OCH}_{3}\right), 3.72(1 \mathrm{H}$, m, H-2') $2.72\left(1 \mathrm{H}, \mathrm{dd}, 13.3,10.1 \mathrm{~Hz}, \mathrm{H}^{\prime} \mathbf{1}^{\prime} \mathrm{a}\right), 2.67\left(1 \mathrm{H}, \mathrm{dd}, J=13.3,2.6 \mathrm{~Hz}, \mathrm{H}-1^{\prime} \mathrm{b}\right), 1.15$ $\left(3 \mathrm{H}, \mathrm{s}, \mathrm{CH}_{3}, \mathrm{H}-3^{\prime}\right), 1.13\left(3 \mathrm{H}, \mathrm{s}, \mathrm{CH}_{3}, \mathrm{H}-3^{\prime}\right) .{ }^{13} \mathrm{C}-\mathrm{NMR}$ (DMSO-d $\left.d_{6}, 100 \mathrm{MHz}\right) \delta_{\mathrm{C}}: 162.3(\mathrm{C}-2)$, 160.6 (C-7), 156.4 (C-5), 154.6 (C-9), 140.1 (C-4), 119.4 (C-10), 112.2 (C-3), 107.0 (C-8), 95.8 (C-6), $77.5\left(\mathrm{C}-2^{\prime}\right), 73.3\left(\mathrm{C}-3^{\prime}\right), 63.5\left(\mathrm{OCH}_{3}, \mathrm{C}-5\right), 56.8\left(\mathrm{OCH}_{3}, \mathrm{C}-7\right), 25.9\left(\mathrm{C}-1^{\prime}\right), 22.1\left(\mathrm{C}-5^{\prime}\right)$, $20.6\left(\mathrm{C}-4^{\prime}\right)$.

Isopimpinellin 5 [31], (peak 5 in Figure 5), $\mathrm{C}_{12} \mathrm{H}_{10} \mathrm{O}_{2}$, ESI-MS (positive ion mode) $\mathrm{m} / \mathrm{z}$ $247.0600[\mathrm{M}+\mathrm{H}]^{+} .{ }^{1} \mathrm{H}-\mathrm{NMR}\left(\mathrm{DMSO}-d_{6}, 400 \mathrm{MHz}\right) \delta_{\mathrm{H}}: 8.19(1 \mathrm{H}, \mathrm{d}, J=9.8 \mathrm{~Hz}, \mathrm{H}-4), 8.10$ $\left(1 \mathrm{H}, \mathrm{d}, J=2.1 \mathrm{~Hz}, \mathrm{H}-2^{\prime}\right), 7.40\left(1 \mathrm{H}, \mathrm{d}, J=2.1 \mathrm{~Hz} . \mathrm{H}-3^{\prime}\right), 6.35(1 \mathrm{H}, \mathrm{d}, J=9.8 \mathrm{~Hz}, \mathrm{H}-3), 4.18(3 \mathrm{H}$, $\left.\mathrm{s}, \mathrm{OCH}_{3}\right), 4.04\left(3 \mathrm{H}, \mathrm{s}, \mathrm{OCH}_{3}\right) .{ }^{13} \mathrm{C}-\mathrm{NMR}\left(\mathrm{DMSO}-d_{6}, 100 \mathrm{MHz}\right) \delta_{\mathrm{C}}: 159.5(\mathrm{C}-2), 149.4(\mathrm{C}-7)$, 146.3 (C-2'), 144.3 (C-5), 143.0 (C-8a), 139.7 (C-4), 127.1 (C-8), 114.4 (C-6), 112.5 (C-3), 106.8 (C-4a), $105.6\left(\mathrm{C}-3^{\prime}\right), 61.2\left(\mathrm{OCH}_{3}\right), 60.8\left(\mathrm{OCH}_{3}\right)$. 
Toddanone 6 [32], (peak 6 in Figure 4), $\mathrm{C}_{16} \mathrm{H}_{18} \mathrm{O}_{5}$, ESI-MS (positive ion mode) $\mathrm{m} / \mathrm{z}$ $291.1184[\mathrm{M}+\mathrm{H}]^{+} .{ }^{1} \mathrm{H}-\mathrm{NMR}\left(\mathrm{DMSO}-d_{6}, 400 \mathrm{MHz}\right) \delta_{\mathrm{H}}: 8.01(1 \mathrm{H}, \mathrm{d}, J=9.7 \mathrm{~Hz}, \mathrm{H}-4), 6.90$ (1H, s, H-8), 6.30 (1H, d, J = 9.7 Hz, H-3), 3.82 (3H, s, OCH 3 , H-7), 3.80 (2H, s, H-11), $3.73\left(3 \mathrm{H}, \mathrm{s}, \mathrm{OCH}_{3}, \mathrm{H}-5\right), 2.79(1 \mathrm{H}, \mathrm{m}, \mathrm{H}-13), 1.09\left(6 \mathrm{H}, \mathrm{d}, J=6.90 \mathrm{~Hz}, 2 \mathrm{CH}_{3}, \mathrm{H}-14, \mathrm{H}-15\right)$. ${ }^{13}$ C-NMR (DMSO- $\left.d_{6}, 100 \mathrm{MHz}\right) \delta_{\mathrm{C}}: 211.4(\mathrm{C}-12), 161.5$ (C-7), 160.5 (C-2), 156.2 (C-5), 155.3 (C-9), 139.7 (C-4), 115.0 (C-6), 112.6 (C-3), 106.9 (C-10), 96.0 (C-8), $63.6\left(\mathrm{OCH}_{3}, \mathrm{C}-5\right), 56.9$ $\left(\mathrm{OCH}_{3}, \mathrm{C}-7\right), 40.3$ (C-13), 35.6 (C-11), 18.6 (C-14), 18.6 (C-15).

\section{Materials and Methods}

\subsection{Reagents and Materials}

HPLC-grade acetonitrile was obtained from the Tedia Company, Inc. (Fairfield, CT, USA). The solvents used for extraction and separation were of analytical grade (Sinopharm Chemical Reagent Co., Ltd., Shanghai, China). The deionized water was disposed by an osmosis Milli-Q system.

The roots of T. asiatica were obtained from a local medicine store in Zhaoqing (Guangxi, China) and identified by Dr. Xiao Wang (Shandong Analysis and Test Center) with a voucher specimen (2018060911) in the Shandong Analysis and Test Center.

\subsection{Apparatus}

TBE-300C HSCCC equipment was used with three multilayer columns of a total of $300 \mathrm{~mL}$ (the diameter of the PTFE tube was $2.6 \mathrm{~mm}$ ) and a $20 \mathrm{~mL}$ sample loop ( Tauto Biotech, Shanghai, China). An LC3050N integrated system was used to contact the HSCCC equipment, composed with a P3050N gradient pump and a UV3050N monitor (Beijing Tong Heng Innovation Technology Co., Ltd., Beijing, China). A DC-0506 low-constanttemperature bath was used to control the temperature at $30^{\circ} \mathrm{C}$. An Agilent 1120 with a Zobax SB $\mathrm{C}_{18}$ column $(5 \mu \mathrm{m}, 250 \mathrm{~mm} \times 4.6 \mathrm{~mm}$, i.d.) was used for the sample detection process (Agilent Technologies, Santa Clara, CA, USA).

\subsection{Preparation of Crude Extract}

The crude sample of T. asiatica was prepared in our laboratory as previously described [22]. Firstly, the dried roots of T. asiatica ( $2 \mathrm{~kg}, 40 \sim 60 \mathrm{mesh})$ were extracted twice under reflux with $5 \mathrm{~L}$ of $95 \%$ ethanol ( $2 \mathrm{~h}$ each time). The extracts were filtrated, combined, and concentrated under vacuum by rotary evaporation at $50{ }^{\circ} \mathrm{C}$. When the ethanol was removed, the $\mathrm{pH}$ was adjusted to 2 with $2 \%$ diluted hydrochloric acid. The solution was extracted three times with isometric petroleum ether, the $\mathrm{pH}$ of the degreased aqueous solution was slowly increased to 8.5 using aqueous ammonia, and the sample was extracted three times with isometric ethyl acetate. The upper ethyl acetate layer was combined and concentrated by rotary evaporation at $50{ }^{\circ} \mathrm{C}$. Finally, the crude extract $(6.3 \mathrm{~g})$ was obtained after vacuum concentration and stored in a refrigerator at $5^{\circ} \mathrm{C}$.

\subsection{Measurement of Partition Coefficient}

The $K_{\mathrm{D}}$ values of the compounds were determined by HPLC. Firstly, different proportions of the solvent systems were prepared in a $5 \mathrm{~mL}$ tube and violently shaken. Two milliliters of each phase of the equilibrated two-phase solvent system was added to the crude extract ( $\sim 3 \mathrm{mg})$. After being shaken vigorously for $1 \mathrm{~min}$ and full separation achieved, $1 \mathrm{~mL}$ of each layer was removed and dried under nitrogen. The remnant was re-dissolved in $1 \mathrm{~mL}$ of methanol and analyzed by HPLC. The $K_{\mathrm{D}}$ value was defined as the peak area of a compound in the stationary phase divided by the peak area of a compound in the mobile phase with the following equation:

$$
K_{\mathrm{D}}=A_{\mathrm{U}} / A_{\mathrm{L}}
$$

where $A_{\mathrm{U}}$ and $A_{\mathrm{L}}$ are the peak areas of target compounds in the stationary and mobile phases, respectively. 


\subsection{Preparation of Solvent System and Sample Solution}

For the LGCCC elution, the solvent systems of $n$-hexane/ethyl acetate/methanol/water $(5: 5: 1: 9, v / v)$ and $(5: 5: 4.5: 5.5, v / v)$ were placed into the individed separating funnel. After being shaken vigorously, the solutions were kept still for several minutes and were separated into two phases for the experiment. The upper organic phase of $n$-hexane/ethyl acetate/methanol/water (5:5:1:9, $v / v)$ was used as the stationary phase. The lower aqueous phase of $n$-hexane/ethyl acetate/methanol/water $(5: 5: 1: 9, v / v)$ was used as mobile A and $(5: 5: 4.5: 5.5, v / v)$ as mobile B. For the off-line 2D isocratic HSCCC elution, the solvent system of $n$-hexane/ethyl acetate/methanol/water (5:5:4:6, $v / v)$ was placed into the separating funnel. After being shaken vigorously, the solutions were kept still for several minutes and were separated into two phases for the experiment. The upper organic phase was used as the stationary phase, while the lower aqueous phase was used as the mobile phase. All the stationary and mobile phases were ultrasonic degassed prior to use.

For the linear gradient HSCCC separation, $200 \mathrm{mg}$ of the crude sample was dissolved in $10 \mathrm{~mL}$ of solution (1:1, upper:lower of HEMW at 5:5:1:9, $v / v)$. For the off-line dimensional HSCCC separation, $45 \mathrm{mg}$ of fraction A in the linear gradient eluton was set in $10 \mathrm{~mL}$ of isometric solution (1:1, upper:lower of HEMW at 5:5:4:6, $v / v)$.

\subsection{HSCCC Separation Procedure}

For the LGCCC separation, the stationary phase was first introduced into the HSCCC column at a flowrate of $20.0 \mathrm{~mL} / \mathrm{min}$. The HSCCC equipment was rotated clockwise at $800 \mathrm{rpm}$ at $30^{\circ} \mathrm{C}$, while mobile phase A was pumped into the CCC column at a flowrate of $5.0 \mathrm{~mL} / \mathrm{min}$ in head-to-tail mode. After the establishment of a hydrodynamic equilibrium, the sample solution was injected through the injection valve. The prescribed mobile phase gradient combinations of A and B (Section 3.5) were applied, and the eluent was continuously monitored with a portable recorder at $320 \mathrm{~nm}$. For the off-line dimensional HSCCC separation, the mobile phase with $n$-hexane/ethyl acetate/methanol/water (5:5:4:6, $v / v$ ) was set at a flowrate of $2.0 \mathrm{~mL} / \mathrm{min}$ in head-to-tail mode and monitored with a portable recorder at $320 \mathrm{~nm}$. All the fractions were collected in $10 \mathrm{~mL}$ test tubes according to UV absorption. The retention of the stationary phase was defined as the stationary phase relative to the total column capacity after separation.

\subsection{HPLC Analysis}

HPLC analyses of crude extract and CCC fractions were performed on an Agilent 1120 apparatus with a Zobax SB $C_{18}$ column $(5 \mu \mathrm{m}, 4.6 \mathrm{~mm} \times 250 \mathrm{~mm}$, i.d.). The HPLC mobile phase comprised of water (A) and acetonitrile (B) with a linear gradient elution of 0-30 $\mathrm{min}, 22-55 \% \mathrm{~B} ; 30-31 \mathrm{~min}, 55-95 \% \mathrm{~B}$; and $34-35 \mathrm{~min}, 95-22 \% \mathrm{~B}$. The flowrate was $1.0 \mathrm{~mL} / \mathrm{min}$, the selected wavelength was $320 \mathrm{~nm}$, and the sample injection volume was $10 \mu \mathrm{L}$.

\subsection{Structural Identification}

The separated compounds were identified by ESI-MS as well as ${ }^{1} \mathrm{H}$ and ${ }^{13} \mathrm{C}$ NMR spectra. The ESI-MS experiment was performed on an Agilent 6520 Q-TOF (Agilent, Santa Clara, CA, USA). NMR spectra were recorded on a Bruker AV-400 spectrometer (Bruker BioSpin, Rheinstetten, Germany) with DMSO. Solvent and chemical shift $(\delta)$ values are expressed, respectively, in parts per million (ppm) and coupling constant $(J)$ in $\mathrm{Hz}$.

\section{Conclusions}

The current study demonstrates an alternate and more efficient separation method using two-dimensional HSCCC linear gradient and isocratic elution modes for the separation of the main components from T. asiatica. Similar to a binary gradient in HPLC, the solvent system was varied by adjusting the proportions of the two solvent systems (lower phase of $n$-hexane/ethyl acetate/methanol/water 5:5:1:9 and 5:5:4.5:5.5). Furthermore, a mixture was separated by off-line 2D-CCC. Six main coumarin moieties, namely, tomentin 
(1), toddalolactone (2), 5,7,8-trimethoxycoumarin (3), mexoticin (4), isopimpinellin (5), and toddanone (6), were efficiently separated, with purities above $98 \%$. The established LG and 2D-CCC provided an efficient method for separating coumarins from T. asiatica. It may also be applied to separate compounds with broad $K_{\mathrm{D}}$ values from other complex natural products.

Author Contributions: Investigation, W.M.; formal analysis, I.A.; writing—original draft preparation, D.W. and I.A.; writing-review and editing, H.H., H.Z., X.S., L.C., L.X. and Y.L.; conceptualization, D.W.; supervision, D.W.; funding acquisition, D.W. All authors have read and agreed to the published version of the manuscript.

Funding: This research received no external funding.

Institutional Review Board Statement: Not applicable.

Informed Consent Statement: Not applicable.

Data Availability Statement: The data presented in this study are available in article.

Acknowledgments: We gratefully acknowledge the Natural Science Foundation of Shandong Province (ZR2020MH396), Science, Education and Industry Integration Innovation Pilot Project of Qilu University of Technology (Shandong Academy of Sciences) (2020KJC-GH08), Key-support Regions Introduce Urgently-needed Talent Projects, and “Double-Hundred Talent Plan” program from Shandong Province. The authors are grateful to the Qilu University of Technology for providing I.A. with postdoctoral funding.

Conflicts of Interest: The authors declare no conflict of interest.

Sample Availability: Samples of the compounds are available from the authors.

\section{References}

1. Schultz, F.; Osuji, O.F.; Wack, B.; Anywar, G.; Garbe, L.A. Antiinflammatory medicinal plants from the Ugandan greater Mpigi region act as potent inhibitors in the COX-2/PGH2 pathway. Plants 2021, 10, 351. [CrossRef] [PubMed]

2. Li, P.; Lei, K.; Ji, L. Characterization of the complete chloroplast genome of Toddalia asiatica (L.) Lam. Mitochondrial DNA B Resour. 2021, 6, 1650-1651. [CrossRef] [PubMed]

3. Lobine, D.; Pairyanen, B.; Zengin, G.; Yilmaz, M.A.; Ouelbani, R.; Bensari, S.; Ak, G.; Abdallah, H.H.; Imran, M.; Mahomoodally, M.F. Chemical composition and pharmacological evaluation and of Toddalia asiatica (Rutaceae) extracts and essential oil by in vitro and in silico approaches. Chem. Biodivers. 2021, 18, e2000999. [CrossRef]

4. Duraipandiyan, V.; Ignacimuthu, S. Antibacterial and antifungal activity of Flindersine isolated from the traditional medicinal plant, Toddalia asiatica (L.) Lam. J. Ethnopharmacol. 2009, 123, 494-498. [CrossRef] [PubMed]

5. Gumisiriza, H.; Sesaazi, C.D.; Olet, E.A.; Kembabazi, O.; Birungi, G. Medicinal plants used to treat 'African' diseases by the local communities of Bwambara sub-county in Rukungiri District, Western Uganda. J. Ethnopharmacol. 2021, 268, 113578. [CrossRef]

6. Pereira, A.S.P.; den Haan, H.; Pena-Garcia, J.; Moreno, M.M.; Perez-Sanchez, H.; Apostolides, Z. Exploring African medicinal plants for potential anti-diabetic compounds with the DIA-DB inverse virtual screening web server. Molecules 2019, $24,2002$. [CrossRef]

7. Rashid, M.A.; Gustafson, K.R.; Kashman, Y.; Cardellina, J.H.; McMahon, J.B.; Boyd, M.R. Anti-HIV alkaloids from Toddalia asiatica. Nat. Prod. Lett. 1995, 6, 153-156. [CrossRef]

8. Zhou, J.W.; Li, Z.Q.; Zhang, J.J.; Wang, H.S.; Yin, S.; Du, J. 8-Acetonyldihydronitidine inhibits the proliferation of human colorectal cancer cells via activation of p53. Eur. J. Pharm. 2019, 854, 256-264. [CrossRef] [PubMed]

9. He, N.; Wang, P.; Wang, P.; Ma, C.; Kang, W. Antibacterial mechanism of chelerythrine isolated from root of Toddalia asiatica (Linn) Lam. Bmc Complement. Altern. Med. 2018, 18, 261. [CrossRef]

10. Nyahanga, T.; Jondiko, J.I.; Manguro, L.O.A.; Orwa, J.A. Antiplasmodial and larvicidal compounds of Toddalia asiatica root bark. J. Chem. Sci. 2013, 125, 1115-1121. [CrossRef]

11. Kavimani, S.; Vetrichel Van, T.; Ilango, R.; Jaykar, B. Antiinflammatory activity of the volatile oil of Toddalia asiatica. Indian J. Pharm. Sci. 1996, 58, 67-70.

12. Tang, Z.H.; Liu, Y.B.; Ma, S.G.; Li, L.; Li, Y.; Jiang, J.D.; Qu, J.; Yu, S.S. Antiviral spirotriscoumarins A and B: Two pairs of oligomeric coumarin enantiomers with a spirodienone-sesquiterpene skeleton from Toddalia asiatica. Org. Lett. 2016, 18, 5146-5149. [CrossRef]

13. Zhou, W.; Luo, C.; Liu, G.; Dong, W.; Zhang, X.; Shen, X. GC-MS analysis of chemical constituents of root bark oil of Toddalia asiatica. Guizhou Yike Daxue Xuebao 2019, 44, 147-152.

14. Liang, J.-1.; Lin, Y.; Liu, L.-y.; Zhou, W.; He, M.-q.; Hao, X.-y. Rapid determination of four categories of pesticide residues in Toddalia asiatica (L.) Lam. by Carb /NH2-SPE-GC-MS. Zhongguo Yaoxue Zazhi (BeijingChina) 2015, 50, $435-441$. 
15. Liu, Z.-G.; Li, Y.; Zhu, F.-F.; He, Y.; Yuan, M.-M.; Xu, M.-J. Study on chemical composition of the essential oil from Toddalia asiatica Lam. by gas chromatography/mass spectrum. Liaoning Zhongyiyao Daxue Xuebao 2011, 13, 150-151.

16. Liu, Z.; Liu, X.; Qin, J. HPLC fingerprint of Toddalia asiatica Lam. Zhongyaocai 2010, 33, 1240-1243.

17. Zhu, M.; Wei, P.; Peng, Q.; Zhou, Y.; Zhang, L.; Qin, S.; Zhang, R.; Zhu, C. Simultaneous qualitative and quantitative evaluation of Toddalia asiatica root by using HPLC-DAD and UPLC-QTOF-MS/MS. Phytochem. Anal. 2019, 30, 164-181. [CrossRef]

18. Liu, Z.-G.; Liu, X.-Y. Determination of pimpinelli and of isopimpinell in root of Toddalia asiatica by HPLC. Liaoning Zhongyiyao Daxue Xиebao 2009, 11, 224-225.

19. Liu, Z.G.; Jiang, M.Y.; Lu, X.M.; Qin, F.; Song, Y.; Wen, J.; Li, F.M. Simultaneous determination of pimpinellin, isopimpinellin and phellopterin in rat plasma by a validated UPLC-MS/MS and its application to a pharmacokinetic study after administration of Toddalia asiatica extract. J. Chromatogr. B 2012, 891, 102-108. [CrossRef] [PubMed]

20. Praveena, C.; Veeresham, C. Quantitative determination of nitidine from roots and plant tissue culture extracts of Toddalia asiatica (Linn.) using HPTLC. Am. J. Anal. Chem. 2014, 5, 65-69. [CrossRef]

21. Qiu, H.Y.; Xiao, X.H.; Li, G.K. Separation and purification of furanocoumarins from Toddalia asiatica (L.) Lam. using microwaveassisted extraction coupled with high-speed counter-current chromatography. J. Sep. Sci. 2012, 35, 901-906. [CrossRef]

22. Cao, C.; Du, P.; Zhu, X.; Yan, H.; Song, X.; Zhu, H.; Geng, Y.; Wang, D. Rapid screening and purification of potential alkaloid neuraminidase inhibitors from Toddalia asiatica (Linn.) Lam. roots via ultrafiltration liquid chromatography combined with stepwise flow rate counter-current chromatography. J. Sep. Sci. 2019, 42, 2621-2627. [CrossRef]

23. Zhu, H.; Chen, L.; Yu, J.Q.; Cui, L.; Ali, I.; Song, X.Y.; Park, J.H.; Wang, D.J.; Wang, X. Flavonoid epimers from custard apple leaves, a rapid screening and separation by HSCCC and their antioxidant and hypoglycaemic activities evaluation. Sci. Rep. 2020, 10, 8819. [CrossRef]

24. Ali, I.; Mu, Y.; Atif, M.; Hussain, H.; Li, J.; Li, D.; Shabbir, M.; Bankeu, J.J.K.; Cui, L.; Sajjad, S.; et al. Separation and antiinflammatory evaluation of phytochemical constituents from Pleurospermum candollei (Apiaceae) by high-speed countercurrent chromatography with continuous sample load. J. Sep. Sci. 2021, 44, 2663-2673. [CrossRef]

25. Ali, I.; Li, J.; Cui, L.; Zhao, H.; He, Q.; Wang, D. Efficient extraction and purification of benzo[c]phenanthridine alkaloids from Macleaya cordata (Willd) R. Br. by combination of ultrahigh pressure extraction and pH-zone-refining counter-current chromatography with anti-breast cancer activity in vitro. Phytochem. Anal. 2021, 32, 423-432. [CrossRef] [PubMed]

26. Chen, J.X.; Huang, S.H.; Wang, Y.; Shao, M.; Ye, W.C. Studies on the chemical constituents from Lobelia chinensis. J. Chin. Med. Mater. 2010, 33, 1721-1724.

27. Liu, Z.; Wang, X.; Mao, B.; Xie, X. Study on chemical constituents of Toddalia asiatica. J. Chin. Med. Mater. 2014, $37,1600-1603$.

28. Sun, W.B.; Yang, Z.; Liang, Y.; Li, L.I.; Hao, X.Y.; Zuo, G.Y.; Zhou, W.; Pharmacy, S.O.; University, G.M. Chemical constituents from n-butanol part in Toddalia asiatica root bark. Chin. Pharm. J. 2018, 53, 1052-1056.

29. Garcia, G.R.M.; Hennig, L.; Rodríguez, E.F.R.; Bussmann, R.W. Coumarins of Loricaria ferruginea. Rev. Bras. Farm. 2016, 26, 471-473. [CrossRef]

30. Chen, X.; Simayi, R.; Long, S. Studies on chemical constituents of Toddalia asiatica stems. Northwest. Pharm. J. 2013, 28, 337-339.

31. Yoo, S.W.; Kim, J.S.; Kang, S.S.; Son, K.H.; Chang, H.W.; Kim, H.P.; Bae, K.; Lee, C.-O. Constituents of the fruits and leaves of Euodia daniellii. Arch. Pharmacal Res. 2002, 25, 824-830. [CrossRef] [PubMed]

32. Zhao, Y.-L.; Yang, X.-W.; Wu, B.-F.; Shang, J.-H.; Liu, Y.-P.; Zhi, D.; Luo, X.-D. Anti-inflammatory effect of pomelo peel and its bioactive coumarins. J. Agric. Food Chem. 2019, 67, 8810-8818. [CrossRef] [PubMed] 